\title{
Conceptual Framework of Employee and Organisation related variables: A Review and Synthesis of Literature
}

\author{
Vaibhav Sharma and Rameez Iqbal Khan ${ }^{* *}$
}

\begin{abstract}
The current environment poses plenty of challenges for practitioners to calculate the interrelation of variables about organizational growth. Although, ample studies delineate the status of the relationship among variables related to employee and organization but studies bringing all the variables in single dice are at a nascent stage. Hence, this study has attempted to explicate the relationship among all variables necessary for organizational growth and proposed a conceptual framework for future researchers. Based on the propositions taken, this literature probe has found variables including employee satisfaction, employee commitment, employee performance, human capital, socially responsible HRM, and firm performance is linked with each other. In the last, this study also sheds a light on future research agenda, limitations, conclusions, and implications for practitioners and researchers.
\end{abstract}

Keywords: Employee Satisfaction, Employee Commitment, Employee Performance, Human Capital, Socially Responsible HRM and Organizational Performance.

\section{INTRODUCTION}

In the 21 st century, Organizations are facing various challenges owing to cut-throat competition in the environment. Thus, management of organizational performance has become a need of hour (Mowdey et al. 2003). Organizations are witnessing the high value of association among employee behavior and organizational performance (Sageer et al. 2012). Consequently, organizations put their efforts to maintain a harmonious relationship with their employees directly and indirectly (Kickul, 2001; Locke and Latham, 1990). Employees are considered to be an asset to the organization. Therefore, Employee performance, satisfaction, and Human capital are coined as the contributor to organizational performance (Hensen and Deimler, 2001; Shore and Martin, 1989; Mowdey et. al. 2003; Bontis and Serenko, 2007). It becomes crucial for an organization to look for socially responsible activities pertained to employee well being. Newman et al. (2014) stress on prevailing rapid environment where the cost of employee turnover has been high. Therefore, organizations are striving hard to engage in such activities where they can mitigate the risk of high employee turnover, and eventually, they can retain their employees for reciprocating the human capital for better organizational performance. In the present literature, these activities are coined as SRHRM (Socially Responsible Human Resource Management) (Newman et al. 2014; Shen and Benson, 2016; Orlitzky and Swanson, 2006; Shen and Zhu, 2011).

Although, there are several studies conducted on employee-related variables like employee satisfaction, employee performance, employee commitment but a study on a linkage of all these variables with SRHRM is still

\footnotetext{
Research Scholar, IBS Hyderabad Email :vaibhavsharma9432@gmail.com (Corresponding Author)

** Associate Professor, Department of Business Administration \& Commerce, Vivek College, Bijnor Email: rameeziqbalkhan@gmail.com
} 
at a nascent stage (Greening and Turban, 2000; Trucker, 2009). Hence, this paper aims to propose a conceptual framework explicating the relationship between employee-related variables and Socially Responsible HRM. The shadow of this study is also shedding a light on the network of all the variables with organizational performance as the variables including Employee Satisfaction, Employee Performance, Employee Commitment, Human Capital, SRHRM are associated with organizational performance.

MethodologyLiterature review is explicated as a systematic, clear, and retrieval source for ascertaining and interpreting the group of traced documents pertained to the research topic (Fink, 1998). The objective of the methodology is analyzing the existing research so that related themes, patterns, and keywords can be mapped (Seuring and Muller, 2008). In this paper, the author(s) explicated the literature in terms of propositions and thus, shaped a conceptual framework. In this regard, a study can be done by implementing content analysis (Seuring and Muller). Content analysis is a method focusing on quantitative as well as qualitative aspects (Kassarjian, H.H, 1977). According to Malhotra and Dash, 2009, Content analysis helps elaborate detailed information regarding past studies.

In this paper, the author(s) have studied 112 research papers and found 106 papers relevant to the concerned issue.

This paper has used the following sources to comprehend past literature.

\section{Emerald Full Text}

2. Wiley Online

3. Taylor and Francis

4. Proquest Online

5. Science Direct

6. JSTOR

\section{Propositions}

\subsection{Employee performance and Employee satisfaction}

According to Mathis and Jackson (2000), "Employee performance is the contribution of employees towards the organization. It can be considered a crucial parameter to analyze the outputs and yields of an organization. Employee performance has also been viewed as a function of ability, motivation, and opportunity (Robbins, 2006). The relationship between employee performance and employee satisfaction has been perceived as an important research practice in industrial-organizational psychology (Judge et al. 2001). Several authors have suggested their views to justify the relationship. Locke's Goal setting theory also delineates that rewards mediate the relationship between employee performance and employee satisfaction (Locke, 1968). This link between employee performance and employee satisfaction has been coined as the "Holy Grail" of the industrial psychologist (Landy, 1989; Judge et al. 2001). The expectancy theory of motivation believes that employee performance exhibits employee satisfaction through rewards and recognition offered to employees (Naylor, 
Pritchard, llgen, 1980; Judge et al. 2001). It has assessed that if employee performance is rewarded then it sheds a light on the positive impact on the satisfaction level of employees (Locke and Latham, 1990, Lawler and Porter, 1967). Satisfied employees tend to show better performance that leads to organizational performance and growth (Ahmad et al. 2014; Biswas and Verma, 2011). According to Ostroff (1992), organizations having satisfied employees perform better than those organizations having dissatisfied employees.

According to Judge et al. (2001), the relationship between employee satisfaction and employee performance is positive but this relationship is mediated by some mediators. These mediators can be job autonomy, organizational culture, organization's reward, and recognition policies, etc. Although plenty of studies are captured in the context of the relationship still, this relationship is considered to be a debatable concern (Judge et al. 2001; Crossman and Zaki, 2003). Due to the debatable nature of the relationship, some studies are reporting negative (Laffaldano and Muchinsky, 1985; Pawirosumarto et al., 2017; Crossman and Zaki, 2003)and spurious link, as well as there, are some studies reporting a positive link between performance and satisfaction (Judge et al. (2001); Norris and Niebuhr, 1984; Jalalkamali et al. 2016; Locke and Latham, 1990). Furthermore, it has been observed that the spurious relationship between two is owing to the relation of these two variables to the third variable which is unmeasured (Judge et al. 2001). Moreover, these statements about the relationship exhibit different propositions. These propositions are as follows.

Proposition 1(a): Employee satisfaction is positively related to employee performance.

Proposition 1(b): Variables like Job autonomy, rewards, compensation, organization culture, leadership, etc mediate the relationship between employee satisfaction and performance.

Proposition 1@: Employee satisfaction is negatively or spuriously related to employee performance.

\subsection{Human capital and Employee performance}

Human capital expresses in terms of accumulated knowledge and skills of the workforce within the period (Danchev and Sevinc, 2012). Individuals who invest higher in Human capital expect to achieve a higher rate of personal job inputs than individuals who invest less in the Human capital (Danchev and Sevinc, 2012; Wan, 2007). It suggests that employees with higher Human capital tend to have a higher expectation of benefits that they should receive from the employer in contrast to employees who have lower Human capital (Balkin and Griffeth, 1993). It is an important component of intellectual capital (Bontis and Serenko, 2007). Organizations that assert inimitable Human capital possess a competitive advantage in the long run (Nonaka and Takeuchi, 1995). Human capital has also been seen as a source of employee innovative performance and employee strategic renewal performance (Bontis and Serenko, 2007). Following 'resource-based theories', employee's human capital makes employee effective performer achieve competitive advantage (Huselid, 1995).

Human capital is reflected by the capabilities of the employee (Bontis and Serenko, 2007). Employee capabilities refer to employee possession of their knowledge, skills, and abilities to perform any task (Bontis and Serenko, 2007). Hence, a significant positive relationship has been noticed between human capital and employee performance (Bontis and Serenko, 2007; Zadeh, 2014; Huselid, 1995). Bansen(2003) also reported a positive relationship between Human capital and employee performance. Furthermore, it has examined that human capital influences employee performance through knowledge sharing (Hsu, 2008). Knowledge sharing aims to improve employee performance and human capital development for the organization's growth (Hsu, 2008). Knowledge sharing improves employee performance either by affecting factors of human capital such as 
knowledge, skills, and abilities or by increasing the motivation level of knowledge workers (Hsu, 2008). All the statements about the relationship between human capital and employee performance lead to some propositions as follows.

Proposition 2(a): Employee performance is positively related to Human capital.

Proposition 2(b): Knowledge sharing mediates the relationship between human capital and employee performance.

\subsection{Employee performance and Employee commitment}

Employee commitment refers to the psychological attachment of employees with their work-place (Allen and Meyer, 1990; O' Reilly and Chatman, 1986). Employee commitment is positively related to outcomes such as employee satisfaction (Bateman and Stressor, 1984; Mowday, Porter and Steers, 1982), intention to stay (Mathieu and Zajac, 1990; Steers and Rhodes, 1978). Although, the Meta-analysis of organizational commitment shows the relationship between employee performance and employee commitment is positive but weak (Mathieu and Zajac, 1990; Chen et al. 2002). Although, overall commitment to the organization tends to be unrelated to employee performance dimensions of employee commitment are found to be related to employee performance (Becker, 1996; Steers, 1977; Wiener and Vardi, 1980; Chen and Francesco, 2003). Essentially, employee commitment is considered as an element having different dimensions (Meyer and Allen, 1991). These are related to their desire, need, and obligation and are termed as affective commitment, normative commitment, and continuance commitment (Meyer and Allen, 1991). Affective commitment demonstrates the emotional attachment of employees with the organization (Meyer and Allen, 1991; Chen et al. 2002) and it has been examined that employee performance can lead to an emotional attachment of employees (Chen et al. 2002). Therefore, affective commitment is found to be positively correlated with employee performance (Meyer et al.1989; Mathieu and Zajac, 1990; Chen et al.2002). Continuance commitment shows a kind of compulsion over employees to continue existing jobs (Meyer and Allen, 1991; Chen et al. 2002) which negatively influences employee performance. Therefore, continuance commitment is found to be negatively related to employee performance (Meyer et al. 1989; Mathieu and Zajac, 1990; Chen et al. 2002). Normative commitment shows that employees prefer to stay with the organization based on a sense of duty, loyalty, or obligation (Chen et al.2002). It moderates the relationship between affective commitment and employee performance (Meyer et al.1989). These findings lead to considering that not overall employee commitment but the certain dimension of employee commitment might be related to employee performance (Becker, 1996).

Hence, these statements lead to derive propositions as follows:

Proposition 3(a): Employee performance is having a weak relationship with Overall commitment.

Proposition 3(b): Employee performance is positively related to affective commitment.

Proposition 3@: Normative commitment moderates the relationship between affective commitment and employee performance.

Proposition 3(d): Continuance commitment is negatively related to employee performance. 


\subsection{Employee performance and Organizational performance}

The resource-based theory considers employee performance as a source of sustained competitive advantage. Furthermore, employee performance is also considered as a determinant of organizational performance (Mathis and Jackson, 2002). Various studies have reported a positive relationship between employee performance and organizational performance (Testa et al. 1998; Hallowell et al. 1996; Heskett et al. 1994; Rucci et al. 1998; Grandzol, 1998; Ryan et al. 1996; Koys, 2001). Employee efficient performance demonstrates that employee is motivated committed and satisfied (Locke and Latham, 1990; Judge et al. 2001; Mathieu and Zajac, 1990). Consequently, satisfied and committed employees generate innovative ideas for new products and services and it improves quality performance, operating performance, and customer satisfaction and reduces employee turn-over costs (Sedikoglu and Zehir, 2010). Improvement in quality performance, operating performance, and level of customer satisfaction positively influence organizational performance (Testa et al. 1996; Grandzol, 1998; Sedikoglu and Zehir, 2010). These improvements assist the organization in reducing quality costs and operating costs and consequently, bring progress in the level of organizational performance. Positive employee performance makes customers delighted for the product they want to consume and extends their consumption by making them loyal to the organization (Hallowell et al. 1996; Heskett et al. 1994; Rucci et al. 1998). This impact of employee performance on customers positively influences organizational performance (Sedikoglu and Zehir, 2010; Grandzol, 1998; Ryan et al. 1996). These statements lead to the following proposition.

Proposition 4(a): There is a positive relationship between employee performance and organizational performance.

\subsection{SRHRM and Employee performance}

Corporate social responsibility is defined as the voluntary incorporation of social and environmental concerns into business operations and their interaction with stakeholders (European Commission, 2002). It is also known as socially responsible human resource management (SRHRM) (Shen and Bensen, 2014). CSR literature asserts on the management of stakeholder groups and perceives employee as an important stakeholder for the organizations (Story and Neves, 2014; Pederson, 2011). Turker (2009) explicates CSR in the context of stakeholder interest and defines it as organizational behavior that aims to affect stakeholders positively. SIT (Social Identity Theory) also emphasizes employee engagement with CSR. SIT states that people engage themselves with CSR to obtain a positive social identity. As result, they get affiliated with high esteemed and socially responsible organizations (Hogg and Abrams, 1988; Trucker, 2009). Employees are considered as a major group demanding CSR (McWilliams and Seagal, 2001). If employees realize that their firm is only chasing profitability and not chasing ethical and legal practices then it decreases their performance and commitment level (Story and Neves ,2014). According to Porter and Kramer (2006), Employees work hard in a socially responsible environment even they don't focus on the monetary gains when they get engaged with socially responsible organizations. In addition to this, it has examined that when an employee perceives himself or herself to be a member of a socially responsible entity, it enhances a shared sense of identification among employee and organization (Nahapiet and Ghoshal, 1998). Therefore, socially responsible organizations foster employee commitment and morale, and consequently, strong commitment leads to greater employee productivity (Porter and Kramer, 2006).

An organization with CSR activities can retain an effective and efficient employee for work on the contrary organization without CSR activities cannot retain an effective and efficient workforce (Story and Neves, 2014; Mirvis, 2012). Therefore, the Organization's CSR activities have been perceived as positive for the organizational performance through their employee performance (Porter and Kramer, 2006). Employee engagement with CSR 
leads to pride in the company (Trucker, 2009; Mirvis, 2012) This engagement is positively related to employee performance and negatively related to employee's intention to quit (Mirvis, 2012). The impact of CSR on the employee is coined as a game-changing trend for the organization (Story and Neves, 2014; Chaudhary, 2018). The literature on CSR or SRHRM and employee performance generate a proposition as follows.

Proposition 5(a): There is a positive relationship between SRHRM and Employee performance.

\subsection{Employee satisfaction and employee commitment}

Employee commitment is considered as an important employee attitude to achieve organization-level outcomes. Employee commitment is viewed as an element having different dimensions. These dimensions are related to desire, need, and obligation which are represented as affective commitment, normative commitment, and continuance commitment (Meyer and Allen, 1991). Meyer and Allen (1991)'s multidimensional model of commitment stated that employee organizational commitment is a mediating variable between individual job related antecedents such as employee satisfaction and organizational outcomes such as organizational performance (Mayer and Allen, 1991; Clugston, 2000). Employee satisfaction is a positive psychological state resulting from one's job (Locke, 1976) and its relationship with employee commitment can be a determinant link for Organizational performance (Angle, 1981; Riketta, 2002) and effectiveness (Laschinger, 2001). Some studies have reported a positive correlation between employee satisfaction and commitment (Benkhoff, 1997; Shore and Martin, 1989; Knoop, 1995; Bateman and Stressor, 1984; Locke and Latham, 1990; Koh and Boo, 2004; Forese and Xiao 2012). Therefore, different concepts have been made in the context of the relationship between employee satisfaction and employee commitment. The concept of employee commitment attempts to understand and elucidate employee's dedication to the organization (Lumley et al. 2011) on the other hand, the concept of employee satisfaction involves employee's affective attachment with the organization and influences the organization's well being concerning organization's productivity (Morrison, 2008; Spector, 2008). Bateman and Strssor (1984) delineate the positive link between employee satisfaction and commitment and consider employee commitment as an antecedent of employee satisfaction instead of the outcome. Employees, who are committed, show a higher level of satisfaction and performance (Mathieu and Zajac, 1990; Wiener and Vardi, 1980; Darden, Hampton and Howell, 1989). When employees are dissatisfied at work then they tend to be less committed and look for opportunities to quit the job (Lok and Crowford 2004). If employees don't get the opportunities then they seek to withdraw from the organization emotionally and mentally (Lok and Crowford, 2004). The level of employee's organizational commitment demonstrates their suitability with extrinsic rewards including remuneration and benefits and psychological rewards including employee satisfaction and attachment with fellow employees (Lumley et al. 2011). These statements regarding the relationship between employee commitment and employee satisfaction form the following proposition for the study.

Proposition 6 (a): There is a positive relationship between employee satisfaction and employee commitment.

Proposition 6 (b): Employee satisfaction and employee commitment are positively related to Organizational performance

\subsection{Human capital and Employee satisfaction}

The relationship between Human capital and employee satisfaction delineates a positive connection between each other (Bontis and Serenko, 2007; Bontis and Fitz-enz, 2002; Echdar, 2015). Human capital can be defined in 
terms of accumulated knowledge and skills of the workforce within the time (Danchev and Sevinc, 2012). Employees who invest more in Human capital attain a higher level of education and expect higher rates of return in terms of benefits or other rewards (Psacharopoulos, 1985; Balkin and Griffeth, 1993). Human capital development is an important effort to gain cost-effective firm performance (Bontis and Serenko, 2007). Hence, firms seek to achieve Human capital that would enhance employee satisfaction and performance (Marmuthu et al. 2009). Human capital development lies in employee sentiments. Moreover, employee sentiments can be defined as a composition of employee satisfaction, commitment, and motivation (Bontis and Fitz-enz, 2002). The development of Human capital is positively influenced by the education level of employees and their overall satisfaction (Danchev and Sevinc, 2012; Marmuthu et al. 2009). Employee satisfaction is an individual's emotional attitude toward his or her job (Locke, 1976). Employee satisfaction has a substantial influence on the Human capital development of the firm directly or indirectly (Bontis and Fitz-enz, 2002). A high level of employee satisfaction provides incentives for employees to improve their performance and to expand their knowledge and skills or to develop their creativity (Danchev and Sevinc, 2012). Human capital involves processes related to training, education, and other initiatives to increase the level of knowledge, skills, abilities, and assets of employees which lead to positive employee satisfaction and eventually positive Organizational performance (Marmuthu et al.2009). This statement leads to the following proposition.

Proposition 7 (a): Higher the level of Human capital, the greater the expectation of benefits or rewards from the employer.

Proposition 7 (b): Human capital is positively related to employee satisfaction.

\subsection{Employee satisfaction and Organizational performance}

Employee satisfaction is considered as a positive attitude that contributes effectively to organizational outcomes (Harter et al. 2002). According to the service-profit chain "Satisfied employees create value in services rendered to the customers". Consequently, this value addition improves Organizational performance (Hasket et al. 1994). Essentially service profit chain is a conceptual model about the link between employee satisfaction and customer satisfaction, customer satisfaction and loyalty, loyalty, and financial performance (Hasket et al. 1994; Loveman, 1994). As whole employee satisfaction is positively related to customer satisfaction and fundamentally, customer satisfaction leads to positive Organizational performance (Wiele, Boselie and Hesselink, 2002; Loveman, 1994; Haskett et al. 1994). The link between employee satisfaction and performance at the organizational level is stronger than the same link at the individual level (Ostroff,1992). This link describes the contribution of employee satisfaction towards organizational financial performance (Based on ROA) and Market performance (Schneider et al.2003). Financially successful organizations are likely to provide perks to employees that enhance the level of employee satisfaction with both job and employing organization(Schneider et al. 2003; Dimitriades and Papalexandris, 2012).

It has been perceived that Organizational performance is gained through the satisfaction of employees and attention to their physical and emotional needs (Ostroff, 1992). Moreover, Employee satisfaction emphasizes the creation of routine patterns. To this, employees create relationships at work that fall into routine patterns, and these patterns influence behaviors. Hence, Employee positive attitudes and behavior in these patterns are directed to achieve organizational goals (Roethlisberger, 1959). Employee satisfaction is a crucial factor in determining employee's behavior and response at work and these behaviors and responses develop organizational effectiveness. Hence, employee satisfaction can result in organizational effectiveness through behaviors about significant productivity (Roethlisberger, 1959; Kopelman et al. 1990). Organizational behavior is reflected by 
organizational effectiveness which promotes Organizational performance (Ostroff, 1992). According to Harter et al. (2002, p.276) "Employee satisfaction has a positive relationship with a business performance at a magnitude that is crucial to many organizations". Employee satisfaction and employee commitment together can be a determinant of Organizational performance (Angle, 1981; Riketta, 2002) and effectiveness (Laschinger, 2001). According to Ostroff (1992, p.963) "Organization with more satisfied employee tends to be more effective than organizations having the less satisfied employee". These statements lead to developing the following proposition.

Proposition 8(a): Greater the employee satisfaction, higher the Organizational performance.

\subsection{SRHRM and Employee satisfaction}

The concept of CSR can be understood through the stakeholder theory (Freeman, 2004). Organizations need to focus on the interest of their stakeholders such as employees, customers, clients, etc during the incorporation of CSR in strategy formulation (Freeman, 2004; Kundu and Gahlawat, 2015). Employee-oriented Corporate social responsibility is a commitment of the organization to employees through responsible leadership. It depicts the extent of employee rights and employee outcomes in a form of employee satisfaction (Cheruiyot and Maru, 2012). CSR is having the potential to create high performance and employee goodwill (Aguilera et al., 2005). CSR literature asserts on the management of stakeholder groups and treats an employee as an important stakeholder for the organizations (Story and Neves, 2014; Pederson, 2011).Trucker (2009) explicates CSR in the context of stakeholder interest and defined it as organizational behavior aims to affect stakeholder positively. SIT (Social Identity Theory) also emphasizes why people engage with CSR. SIT states that people engage with CSR to seek a positive social identity. As a result, employees affiliate with high esteemed and socially responsible organizations (Hogg and Abrams, 1988; Trucker, 2009). Moreover, 'Soft HRM' or CSR helps in developing the employee social identity to a new level which in turn enhances employee satisfaction. (Kundu and Gahlawat, 2015; Brammer et al. 2007). Employees are considered as a major group demanding CSR (McWilliams and Seagal, 2001). If employees realize that their firm is only chasing profitability and not chasing ethical and legal practices then it decreases their satisfaction and commitment level (Story and Neves ,2014). According to Porter and Kramer (2006), Employees work hard in a socially responsible environment even they don't focus on the monetary gains when they get engaged with socially responsible organizations. When an employee perceives himself or herself to be a member of a socially responsible entity, it enhances a shared sense of identification among employees and the organization (Nahapiet and Ghoshal, 1998). Therefore, socially responsible organizations foster employee commitment and morale, and consequently, strong commitment leads to greater employee satisfaction (Koh and Boo, 2004).

Social exchange theory proposes a framework to explain how employee perception of socially responsible HRM is associated with employee satisfaction (Masterson, 2000). Kundu (2013) states that an organization's appreciation of employees as an ethical HR strategy helps in enhancing positive employee satisfaction. O'Donohue and Nelson (2009) state that CSR or socially responsible HRM practices frames better alignment of interests, goals, and values of employees with the organization. Employee satisfaction is positively related to socially responsible HRM or CSR (Glavas and Kelley, 2014; Closon et al 2015; Kundu and Gahlawat, 2015).

Proposition 9 (a): Socially responsible HRM Practices are positively related to employee satisfaction.

\subsection{Human capital and Employee commitment}

Organizational commitment theory states that employees in an organization may prefer to stay and apply their Human capital in an organization even if the monetary return on their investment is low (Verkhohlyad and 
Mcclean, 2012). Human capital consists of employee's qualities, abilities, skills, knowledge, and experience that make employees economically productive (Becker, 1964; Heckman, 2000). The human capital theory aims to invest in the development of Human capital to obtain qualified individuals. It has been perceived that the more the organization invests in Human capital via HRM activities, the higher the potential for employee's contribution towards the firm (Chan and Chen, 2011). Employee commitment and Human capital both are considered strong contributors to HPWS (High-performance work practices) (Mansour et al. 2014). Employee affective commitment and Human capital mediate the relationship between High-performance work practices of an organization and employee performance (Chang and Chen, 2011).

Proposition 10(a): Employee commitment and Human capital mediate the relationship between highperformance work practices and employee performance

\subsection{Employee commitment and Organizational performance}

Employee organizational commitment is a psychological state that demonstrates an employee's bonding with the organization (Rashid et al. 2003). A committed employee stays with the organization in a hard time, works regularly, and protects an organization's assets, shares, goals, and others. Thus, having committed employees is an additional advantage to the organization (Meyer and Allen, 1997). Lee and Miller (1999) stated a positive relationship between employee commitment and ROA (Return on asset). This implies that employee commitment could positively influence organizational performance. It has been found that the more committed the employees, the greater the return to shareholders (Conchas, 2000). Allen and Meyer(1990) established a commitment model describing three types of commitments. These commitments are affective, continuance, and normative. Affectively committed employees contribute more towards Organizational performance than continuance and normative commitment (Rashid et al. 2003; Riketta, 2002). Attitudinal organizational commitment or affective commitment positively influences all those behaviors which are beneficial to the organization such as Organizational performance, attendance, staying with the organization (Mathieu and Zajac, 1990; Meyer and Allen, 1997; Randall, 1990). Employee commitment has been considered as an extent to which an employee identifies his or her firm and shares its value and goals (Fields, 2002; Meyer et al. 1993). Employees with high commitment treat their company as an organization for which they feel proud to work (Alfalla-Luque et al. 2012). Consequently, they start working hard for the high performance of the organization and tend to be prepared for accepting any task (Kuo, 2013). The literature on workforce management considers employee commitment as an important construct for explaining Organizational performance (Guest and Conway, 2011; Alfalla-Luque and Marin-Garcia, 2013). These statements develop a proposition as follows.

Proposition 11(a): Employee commitment is positively related to organizational performance.

\subsection{Human capital and Organizational performance}

Human capital is a key component of the intellectual capital of contemporary organizations (Nonaka and Takeuchi, 1995). Companies that emphasize Human capital possess a competitive advantage for a prolonged period (Nonaka and Takeuchi, 1995; Bontis and Serenko, 2007). Human capital is an important source of organizational growth as well as the economic prosperity of a country (Ulrich, 1998; Bontis, 2004). Human capital is a tool of innovation and strategy renewal (Bontis and Serenko, 2007). Human capital depicts the employee knowledge stock of an organization as shown by its employees (Bontis, 2001). According to Roos et al. (1997), employees generate intellectual capital via their competence, attitude, and intellectual agility. Competence consists of skills and education, while attitude refers to a behavioral component of an employee, and 
intellectual agility specifies the capability of the employee to think the innovative solution to problems (Bontis et al. 2000). Human capital demonstrates the knowledge, skills, and abilities of employees (Bontis and Serenko, 2007), and KSA's in employees facilitate the creation of organization well-being where the employees are working (OECD, 2001, p.18). Human capital is a fundamental source of economic productivity (Romer, 1990) as well. Furthermore, Human capital philosophy states that there is a positive relationship between innovativeness and organizational performance. Bontis (1998) elucidates Human capital as the firm's collective ability to elicit the best solutions from the knowledge of its employees to obtain positive Organizational performance. Several studies reported that Human capital will result in greater competitiveness and performance (Agarwala, 2003; Bontis and Serenko, 2007). These statements lead to developing the following proposition.

Proposition 12(a): There is a positive relationship between Human capital and Organizational performance.

\subsection{SRHRM and Employee commitment}

Several studies have been conducted in the context of the relationship between socially responsible human resource management (SRHRM) and employee commitment (Turker, 2009; Ellemers et al. 2011; Shen and Zhu, 2011). Socially responsible human resource management is concerned with stakeholders including employee, customer, shareholder, etc (Carroll, 1998; Hopkins, 2003; Lee, 2008). Although, it is widely known that effective HRM contributes to Organizational performance (Wright et al. 2005). Socially responsible HRM impacts Organizational performance through its influence on employee attitudes and behaviors such as commitment and performance (Storey, 1989). Prior studies have found that socially responsible HRM fosters organizational status with customers, encourages employees (Wilson 1997), and enhances Organizational performance (Hannon and Milkovich, 1996). According to McWilliams and Seagal(2001), Employees are considered as a major group demanding CSR. If employees realize that their firm is only chasing profitability and not chasing ethical and legal practices then it decreases their satisfaction and commitment level (Story and Neves 2014). According to Porter and Kramer (2006), Employees work hard in a socially responsible environment even they don't focus on the monetary gains when they get engaged with socially responsible organizations. Employee prefers to stay at such organizations which promote socially responsible activities (Nahapiet and Ghoshal, 1998). According to Stawiski et al. (2010), the Good deeds of the organization create a sense of belongingness among the employees. Organizations with socially responsible HRM and high employee commitment tend to perform better so it can be said that both are the determinants of organizational performance (Ali, et al. 2010; Stawiski et al. 2010). Furthermore, a study by Shen and Zhu (2011) concludes that higher the socially responsible HRM leads to higher employee commitment.

These statements lead to developing the following propositions.

Proposition 13 (a): SRHRM is positively related to employee commitment

Proposition 13(b): SRHRM and Employee commitment both are positively related to organizational performance.

\subsection{SRHRM and Organizational performance}

Research on Corporate Social Responsibility or Socially responsible HRM practice is a considerable concept that has highlighted the positive bonding between social responsibility and business opportunities in terms of 
productivity, competitive edge, and employee competence (Porter and Kramer, 2002). It has been argued that good social and environmental practice adds value to the organization in terms of performance and productivity (Lu et al, 2009). According to Caroll (1979) and Joyner and Paine, (2002), A CSR oriented firm can enhance the value of its intangible assets such as knowledge, a trust which underpins the value process of value creation. In addition to this, the resource-based view suggests that firms that have valuable assets possess a competitive advantage and may get efficient Organizational performance (Roberts and Dowling, 2002). Furthermore, it has also been perceived that firms whose assets are difficult to imitate may gain superior financial performance (Barney, 1991).

Previous studies have hypothesized socially responsible HRM and Organizational performance to be positively related (Lu et al. 2009). According to an OECD report (2001), organizations involved in SRHRM initiatives drive a range of benefits. (1). It shrinks the risk of costly criminal prosecutions, litigation, (2). It improves an organization's morale, (3). It improves the organization's goodwill, (4). It improves sales and makes customers' brand loyal, and so on. According to Orlitzky (2005), SRHRM enhances the share value of the company in the financial market.

Several studies have reported a positive relationship between SRHRM and organizational performance (Caroll, 1979; Lu et al. 2009; Barney, 1991; Orlitzky, 2005; Rettab et al. 2008; Torugsa et al. 2012). The above statements lead to the following proposition.

Proposition 14 (a): SRHRM is positively related to Organizational performance

\subsection{SRHRM and Human capital}

Human capital is considered as a component of intellectual capital derived from employee's competencies (Bontis and Serenko, 2007; Casalegno et al. 2017). Most of the studies have found that Human capital enables the firm to face competition by making them competitive (Casalegno et al. 2017). According to Casalegno and Pellicelli, (2008) organizations with more Human capital can create a high value of share-holders in contrast to organizations with less Human capital. The relationship between CSR and Human capital has been perceived as positive (Casalegno et al. 2017; E, Startseva et al. 2015). Human capital can be strengthened by the implementation of CSR activities. CSR concept promotes responsible practices and it cannot be denied that these responsible practices lead to derive positive repercussions in the context of business organization (Porter and Kramer, 2011). Therefore, every organization strives tough to become responsible (Coulon, R. 2006). CSR has been perceived as a subject of strategy implementation, marketing, products, communication, and human resource management, finance, stakeholder relations, and many more (Casalegno et al. 2017). Fundamentally, Human capital is recognized as a set of employee's knowledge, skills, competencies, and other qualities (Schultz, 1961; Becker, 1964). Management of knowledge, skills, and abilities promote employee well being along with social and economic well being which are the dimensions of CSR or SRHRM (Keeley, 2007). According to Casalegno et al. (2009), SRHRM practices have a positive impact on Human capital management. CSR practices towards Human capital can be summed up as Health and Safety practices for employees, Employee rights, WorkLife Balance, Training and Development, etc.

All these statements lead to the following proposition

Proposition 15(a): SRHRM is positively related to Human capital 


\section{CONCEPTUALFRAMEWORK}

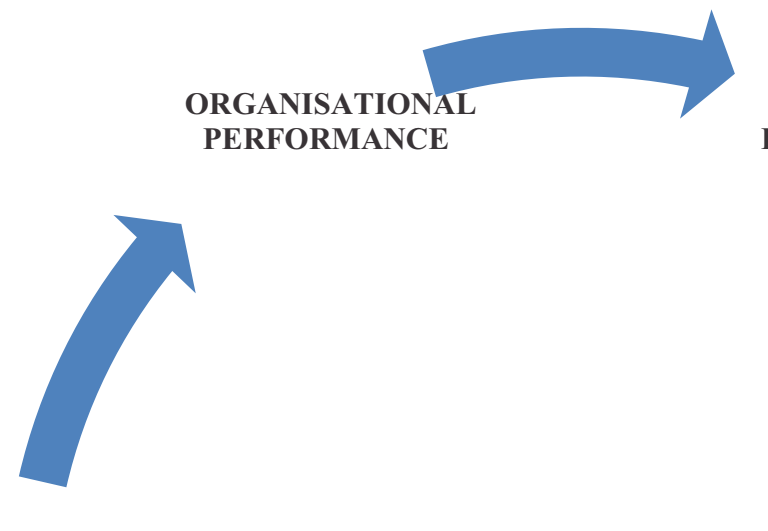

EMPLOYEE
ERFORMANCE

HUMAN CAPITAL

SRHRM
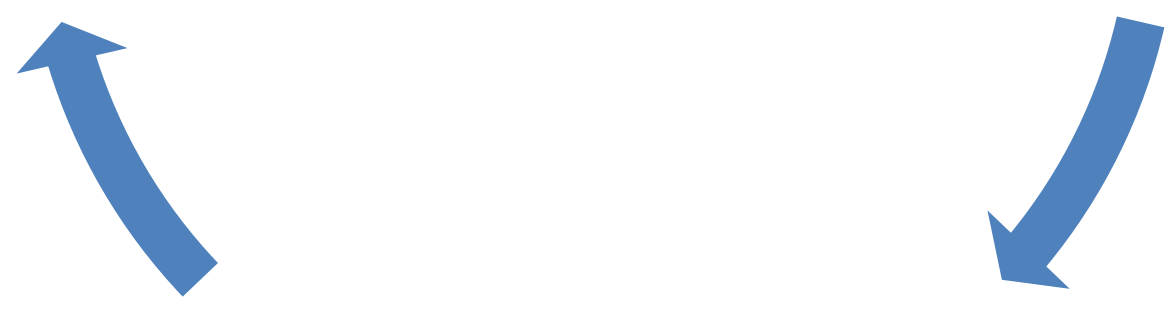

EMPLOYEE COMMITMENT

EMPLOYEE SATISFACTION

All the variables in the above framework are inter-related, as has been seen from the literature studied. None of the variable acts as an independent variable as the commitment of one depends on the other. All five variables, i.e., employee performance, human capital, employee commitment, employee satisfaction, and SRHRM, directly relate to organizational performance. So for the growth of an organization, it is necessary to study the relationship between all the employee-related variables individually with SRHRM and study their relationship cycle. This conceptual framework depicts that for organizational performance, employee performance is vital. For employee performance, SRHRM will perform as a crucial part. SRHRM leads to employee satisfaction, which positively affects employee commitment and paves the path for human capital. And this whole process contributes to organizational performance.

\section{IMPLICATIONS FOR INDUSTRY}

SRHRM significantly predicts organizational competitiveness, which in turn leads to organizational performance. This study has a valid implication for the industry part. Understanding the multivariate concept shall enhance the organization's efficiency as a whole and employee as an individual. Employee satisfaction, employee performance, employee commitment, Human Capital, SRHRM all have been considered to be turning points in the development of positive organizational performance (Lu et al. 2009; Rettab et al. 2008; Sedikoglu and Zehir, 2010; Laschinger, 2001; Ostroff, 1992; Harter et al. 2002), that is why a study on employees and organizations is 
an ingredient for the healthy literature. Moreover, this study ascertains that all these variables simultaneously are important for an organization's health. This study will be a helping concern for managers to frame strategic policies for their companies. Hence, this paper will assist managers and practitioners in their working endeavors.

\section{IMPLICATIONS FOR RESEARCHERS AND PRACTITIONERS}

This study is also vital from an academic perspective. It sheds light on past studies elaborating all the variables, including employee performance, human capital, employee satisfaction, employee commitment, socially responsible human resource management, and last organizational performance. Even though this study is explicating all the possible linkages and proposing a conceptual framework established by past literature, literature based on past studies consists of certain limitations. For instance, past studies could have restricted because of gaps about small sample size, method of collecting the data, common method biases, meta-analysis, etc. Therefore, this study stresses on academic researchers and practitioners to consider these gaps for their research agenda. Future research can use the proposed framework for empirical research. Empirical studies pertained to this framework will help in providing more valid results.

\section{CONCLUSION \& FUTURE RESEARCHAGENDA}

In this study, literature pertained to all variables necessary for organizational performance has been studied. It has been found that all the variables are related to each other and are contributors to positive organizational performance. In this paper, the authors have delineated the pattern of links among all the variables, and thus, elaborated their status of relationship whether it is positive or negative.

Authors have relied on past literature to form propositions. However, to investigate generalizability, it is required to test propositions empirically in different conditions. The nature of the paper is conceptual, so empirical research is must get conclusive results. To this, proper fieldwork and case studies are required to strengthen the relationships among variables. Furthermore, different countries give different results owing to different markets and industries. Hence, it is impossible to replicate one country's result in another (Business system theory, Whitley, 1992). It suggests that future researchers need to test the propositions for different countries, industries, markets, and other environmental variables. According to Arora and Rahman (2016), testing propositions for different industries, countries, and markets can generate knowledge for researchers and practitioners.

\section{LIMITATIONS}

Moreover, this paper puts forth limitations regarding variables, sample, Methodology. In the context of this, this study incorporates a simple methodology for selecting past literature based on the variables taken. It can be possible that papers addressing the same variables with different terminology might have been excluded. Likewise, SRHRM has been coined as CSR in ample of studies. Moreover, some papers delineating the variables, not at the core, can get included and presented as a reference in review research.

\section{REFERENCES}

Abdul Rashid, Z., Sambasivan, M., \&Johari, J. (2003), The influence of corporate culture and organizational commitment on performance. Journal of management development, 22(8), 708-728. 
Abrams, D., \& Hogg, M. A. (1988). Comments on the motivational status of self-esteem in social identity and intergroup discrimination. European journal of social psychology, 18(4),317-334.

Agarwala, T. (2003), Innovative human resource practices and organizational commitment: An empirical investigation. International Journal of Human Resource Management, 14(2), 175-197.

Ahmad, M., Shahzad, N., Waheed, A., \& Khan, M. (2014). High Involvement Management and Employees Performance Mediating Role of Job Satisfaction. European Journal of Business and Management, 6(31), 230-243.

Alfalla-Luque, R., Marín-García, J. A., \& Medina-López, C. (2012), Is worker commitment necessary for achieving competitive advantage and customer satisfaction when companies use HRM and TQM practices? Universia Business Review, (36).

Alfalla-Luque, R., Marin-Garcia, J. A., \& Medina-Lopez, C. (2015), An analysis of the direct and mediated effects of employee commitment and supply chain integration on organizational performance. International Journal of Production Economics, 162, 242-257.

Ali, I., Rehman, K. U., Ali, S. I., Yousaf, J., \& Zia, M. (2010), Corporate social responsibility influences, employee commitment, and organizational performance. African journal of Business management, 4(13), 2796.

Allen, N. J., \& Meyer, J. P. (1990), The measurement and antecedents of affective, continuance and normative commitment to the organization. Journal of occupational and organizational psychology, 63(1), 1-18.

Angle, H. L., \& Perry, J. L. (1981), An empirical assessment of organizational commitment and organizational effectiveness. Administrative science quarterly, 26(1), 1-14.

Balkin, D. B., \& Griffeth, R. W. (1993). The determinants of employee benefits satisfaction. Journal of Business and Psychology, 7(3), 323-339.

Barney, J. (1991), Firm resources and sustained competitive advantage. Journal of management, 17(1), 99-120.

Bateman, T. S., \&Strasser, S. (1984), A longitudinal analysis of the antecedents of organizational commitment.Academy of managementjournal,27(1), 95-112.

Becker, T. E., Billings, R. S., Eveleth, D. M., \& Gilbert, N. L. (1996), Foci and bases of employee commitment: Implications for job performance. Academy of management journal, 39(2), 464-482.

Benkhoff, B. (1997), Ignoring commitment is costly: New approaches establish the missing link between commitment and performance. Human relations, 50(6), 701-726.

Biswas, S., \& Varma, A. (2012). Antecedents of employee performance: an empirical investigation in India. Employee Relations.

Bontis, N. (1998), Intellectual capital: an exploratory study that develops measures and models. Management decision, 36(2), 63-76.

Bontis, N. (2001), Assessing knowledge assets: a review of the models used to measure intellectual capital. International journal of management reviews, 3(1), 41-60.

Bontis, N. (2004), National intellectual capital index: a United Nations initiative for the Arab region. Journal of intellectual capital, 5(1), 13-39.

Bontis, N. and Serenko, A. (2007), The moderating role of human capital management practices on employee capabilities. Journal of Knowledge Management, 11(3), 31-51.

Bontis, N., \& Fitz-Enz, J. (2002), Intellectual capital ROI: a causal map of human capital antecedents and consequents. Journal of Intellectual capital, 3(3), 223-247.

Bontis, N., Chua Chong Keow, W., \& Richardson, S. (2000), Intellectual capital and business performance in Malaysian industries.Journal of intellectual capital, 1(1), 85-100.

Brammer, S., Millington, A., \&Rayton, B. (2007), The contribution of corporate social responsibility to 
organizational commitment. The International Journal of Human Resource Management, 18(10), 17011719.

Bučiūnienė, I., \&Kazlauskaitè, R. (2012), The linkage between HRM, CSR and performance outcomes. Baltic Journal of Management, 7(1), 5-24.

Caroll, M. E., \&Meisch, R. A. (1979), Concurrent etonitazene and water intake in rats: Role of taste, olfaction, and auditory stimuli. Psychopharmacology, 64(1), 1-7.

Carroll, A. B. (1998), The four faces of corporate citizenship. Business and society review, 100(1), 1-7.

Casalegno, C., \&Pellicelli, M. (2008), The human capital impact on the shareholder value creation. EconomiaAziendale Online, 1(2-3), 1-31.

Casalegno, C., Pellicelli, M., \&Civera, C. (2017), CSR and human capital as levers for enhancing shareholder value creation.An early investigation of the largest European companies. Global Business and Economics Review, 19(4), 448-467.

Chang, P. C., \& Chen, S. J. (2011), Crossing the level of employee's performance: HPWS, affective commitment, human capital, and employee job performance in professional service organizations. The international journal of human resource management, 22(04), 883-901.

Chaudhary, R. (2018), Corporate social responsibility and employee performance: a study among indian business executives. The International Journal of Human Resource Management, 1-24.

Chen, Z. X., \& Francesco, A. M. (2003), The relationship between the three components of commitment and employee performance in China. Journal of vocational behavior, 62(3), 490-510.

Chen, Z. X., Tsui, A. S., \&Farh, J. L. (2002), Loyalty to supervisor vs. organizational commitment: Relationships to employee performance in China. Journal of occupational and organizational psychology, 75(3), 339-356.

ChyeKoh, H. and Boo, E.F.H. (2004), Organizational ethics and employee satisfaction and commitment. Management Decision, 42(5), 676-693.

Closon, C., Leys, C., \&Hellemans, C. (2015).Perceptions of corporate social responsibility, organizational commitment and job satisfaction.Management Research: The Journal of the Iberoamerican Academy of Management, 13(1), 31-54.

Clugston, M. (2000).The mediating effects of multidimensional commitment on job satisfaction and intent to leave.Journal of organizational behavior, 21(4), 477-486.

Conchas, E. (2000), Company profits tied to employee commitment. Dallas Business Journal, 2(29), 37-48.

Crossman, A., \& Abou-Zaki, B. (2003). Job satisfaction and employee performance of Lebanese banking staff. Journal of Managerial Psychology.

DANCHEV, A., \& SEVINC, E. (2012), Willingness to Work, Human Capital and Job Satisfaction: A Case Study for Turkey. Eurasian Journal of Business and Economics, (5), 71-90.

Darden, W. R., Hampton, R., \& Howell, R. D. (1989), Career Versus Organizational Commitment: Antecedents And Con. Journal of Retailing, 65(1), 80.

Darden, W. R., Hampton, R., \& Howell, R. D. (1989). Career Versus Organizational Commitment: Antecedents And Con. Journal of Retailing, 65(1), 80.

De la Torre-Ruiz, J.M., Vidal-Salazar, M.D. and Cordón-Pozo, E.(2017), Employees are satisfied with their benefits, but so what? The consequences of benefit satisfaction on employees' organizational commitment and turnover intentions. The International Journal of Human Resource Management, 1-24.

Dimitriades, Z. S., \&Papalexandris, N. (2012). Job and organizational attitudes in relation to financial performance in Greek retail banking: an exploratory empirical investigation. The International Journal of Human Resource Management, 23(4), 793-807.

Du, S., Bhattacharya, C. B., \&Sen, S. (2010), Maximizing business returns to corporate social responsibility 
(CSR): The role of CSR communication. International Journal of Management Reviews, 12(1), 8-19.

Echdar, S. (2015).Human capital development strategy on go-public manufacturing companies in Indonesia.Journal of Economics, Business \& Accountancy Ventura, 18(1), 103-120.

Ellemers, N., Kingma, L., van de Burgt, J., \&Barreto, M. (2011). Corporate social responsibility as a source of organizational morality, employee commitment and satisfaction.Journal of organizational Moral psychology, 1(2), 97-124.

European Commission.Directorate-General for Employment, \& Social Affairs.Unit D. (2002).Corporate Social Responsibility: A business contribution to sustainable development. Office for Official Publications of the European Communities.

Fields, D. L. (2002), Taking the measure of work: A guide to validated scales for organizational research and diagnosis. Sage.

Foote, J., Gaffney, N. and Evans, J.R., 2010, Corporate social responsibility: Implications for performance excellence. Total Quality Management, 21(8), pp.799-812.

Froese, F. J., \& Xiao, S. (2012), Work values, job satisfaction and organizational commitment in China. The International Journal of Human Resource Management, 23(10), 2144-2162.

Glavas, A., \& Kelley, K. (2014), The effects of perceived corporate social responsibility on employee attitudes. Business Ethics Quarterly, 24(2), 165-202.

Grandzol, J. R., \&Gershon, M. (1998), A survey instrument for standardizing TQM modeling research. International Journal of Quality Science, 3(1), 80-105.

Greening, D. W., \& Turban, D. B. (2000), Corporate social performance as a competitive advantage in attracting a quality workforce. Business \& Society, 39(3), 254-280.

Guest, D., \& Conway, N. (2011). The impact of HR practices, HR effectiveness and a 'strong HR system'on organizational outcomes: a stakeholder perspective. The international journal of human resource management, 22(8), 1686-1702.

Guthrie, J. P., Flood, P. C., Liu, W., \&MacCurtain, S. (2009). High performance work systems in Ireland: human resource and organizational outcomes. The International Journal of Human Resource Management, , 20(1), $112-125$.

Hallowell, R. (1996), The relationships of customer satisfaction, customer loyalty, and profitability: an empirical study. International journal of service industry management, 7(4), 27-42.

Hannon, J. M., \&Milkovich, G. T. (1996), The effect of human resource reputation signals on share prices: An event study. Human Resource Management, 35(3), 405-424.

Hansen, M.T. and Deimler, M.S.(2001), Cutting costs while improving morale with B2E management. MIT Sloan Management Review, 43(1), 96.

Harter, J.K., Schmidt, F.L. and Hayes, T.L. (2002), Business-unit-level relationship between employee satisfaction, employee engagement, and business outcomes: a meta-analysis. Journal of applied psychology, $87(2), 268$.

Heckman, J. J. (2000), Policies to foster human capital. researchin economics, 54(1), 3-56.

Heskett, J. L., Jones, T. O., Loveman, G. W., Sasser, W. E., \& Schlesinger, L. A. (1994), Putting the service-profit chain to work. Harvard business review, 72(2), 164-174.

Hogg, M. A., \&Abrams, D. (1988), Social identifications.

Hopkins, M. (2003), The business case for CSR: where are we?.International Journal of Business Performance Management, 5(2-3), 125-140.

Hsu, I. C. (2008). Knowledge sharing practices as a facilitating factor for improving organizational performance through human capital: A preliminary test. Expert Systems with applications, 35(3), 1316-1326. 
Huselid, M. A. (1995), The impact of human resource management practices on turnover, productivity, and corporate financial performance. Academy of management journal, 38(3), 635-672.

Iles, P., Mabey, C., \& Robertson, I. (1990), HRM practices and employee commitment: Possibilities, pitfalls and paradoxes. British Journal of Management, 1(3), 147-157.

Innocenti, L., Pilati, M., \&Peluso, A. M. (2011). Trust as moderator in the relationship between HRM practices and employee attitudes. Human Resource Management Journal, 21(3), 303-317.

Jaksic, M. and Jaksic, M.(2013), Performance management and employee satisfaction. Montenegrin journal of economics, $9(1), 85$.

Jalalkamali, M., Ali, A.J., Hyun, S.S. and Nikbin, D.(2016), Relationships between work values, communication satisfaction, and employee job performance: The case of international joint ventures in Iran. Management Decision, 54(4), 796-814.

Judge, T.A. and Bono, J.E.(2001), relationship of core self-evaluations traits-self-esteem, generalized selfefficacy, locus of control, and emotional stability - with job satisfaction and job performance: A metaanalysis. Journal of applied Psychology, 86(1),80.

Keeley, B. (2007). OECD insights: Human capital. Paris: Organization for Economic Cooperation and Development.

Keinert, C. (2008). Corporate social responsibility as an international strategy. Springer Science \& Business Media.(https://books.google.com/books?hl=en\&lr=\&id=de0o4XkPIYYC\&oi=fnd\&pg=P A1\&dq=(13)\%0 9Keinert, + C. $+(2008) .+$ Corporate + social + responsibility + as + an + international + strategy.+ Springer + Science $+\% 26+$ Business + Media.\&ots=e1US94Jx4N\&sig=O1PEBqV5dGeaPcUvXUIuL-Dof6I)

KimeliCheruiyot, T. and ChemngetichMaru, L. (2014), Corporate human rights social responsibility and employee job outcomes in Kenya. International Journal of Law and Management, 56(2), 152-168.

Kinnie, N., Hutchinson, S., Purcell, J., Rayton, B. and Swart, J.(2005), Satisfaction with HR practices and commitment to the organization: why one size does not fit all. Human Resource Management Journal, 15(4), 9-29.

Kirmeyer, S. L., \& Lin, T. R. (1987). Social support: Its relationship to observed communication with peers and superiors. Academy of Management Journal, 30(1), 138-151.

Knoop, R. (1995), Relationships among job involvement, job satisfaction, and organizational commitment for nurses. The journal of psychology, 129(6), 643-649.

Kopelman, R. E., Brief, A. P., \&Guzzo, R. A. (1990), The role of climate and culture in productivity. Organizational climate and culture, 282,318.

Kotler, P., \& Lee, N. (2005). Corporate Social Responsibility: Doing the Most Good for Your Company and Your Cause". John Wiley \& Sons Inc. Hoboken, New Jersey.

Koys, D. J. (2001), The effects of employee satisfaction, organizational citizenship behavior, and turnover on organizational effectiveness: A unit level, longitudinal study. Personnel psychology, 54(1), 101-114.

Kundu, S. C. R. (2013), Effect of employee supportive HR practices on HR outcomes: A case of dual career couples. IRC's International Journal of Multidisciplinary Research in Social \& Management Sciences, 1(3), 91-100.

Kundu, S. C., \&Gahlawat, N. (2015). Socially responsible HR practices and employees' intention to quit: The mediating role of job satisfaction. Human Resource Development International, 18(4), 387-406.

Kuo, Y. K. (2013), Organizational commitment in an intense competition environment. Industrial Management \& Data Systems, 113(1), 39-56.

Laffaldano, M.T. and Muchinsky, P.M.(1985), Job satisfaction and job performance: A meta-analysis. Psychological bulletin, 97(2), 251. 
Lai Wan, H.(2007), Human capital development policies: enhancing employees' satisfaction. Journal of European industrial training, 31(4), 297-322.

Laschinger, H. K. S., Shamian, J., \& Thomson, D. (2001), Impact of magnet hospital characteristics on nurses' perceptions of trust, burnout, quality of care, and work satisfaction. Nursing economics, 19(5), 209.

Lawler, E. E., \& Porter, L. W. (1967), The effect of performance on job satisfaction. Industrial relations: A journal of Economy and Society, 7(1), 20-28.

Lee, J., \& Miller, D. (1999), People matter: Commitment to employees, strategy and performance in Korean firms. strategic management journal, 20(6), 579-593.

Lee, M. D. P. (2008), A review of the theories of corporate social responsibility: Its evolutionary path and the road ahead. International journal of management reviews, 10(1), 53-73.

Lester, S.W. and Kickul, J.(2001), Psychological contracts in the 21st century: What employees value most and how well organizations are responding to these expectations. People and Strategy, 24(1), 10.

Locke, E. A. (1968), Toward a theory of task motivation and incentives. Organizational behavior and human performance, 3(2), 157-189.

Locke, E.A. and Latham, G.P. (1990), Work motivation and satisfaction: Light at the end of the tunnel. Psychological science, 1(4), 240-246.

Locke, E.A.(1976), The nature and causes of job satisfaction", Handbook of industrial and organizational psychology.

Lok, P., \& Crawford, J. (2004), The effect of organizational culture and leadership style on job satisfaction and organizational commitment: A cross-national comparison. Journal of management development, 23(4), 321338.

Loveman, G. W. (1994), An assessment of the productivity impact of information technologies. Information technology and the corporation of the 1990s: Research studies, 84, 110.

Lu, C. S., Lin, C. C., \&Tu, C. J. (2009), Corporate social responsibility and organizational performance in container shipping. International Journal of Logistics: Research and Applications, 12(2), 119-132.

Lumley, E. J., Coetzee, M., Tladinyane, R., \& Ferreira, N. (2011), Exploring the job satisfaction and organizational commitment of employees in the information technology environment. Southern African Business Review, 15(1), 100-118.

Mansour, N., Gara, E., \&Gaha, C. (2014), Getting inside the black box: HR practices and firm performance within the Tunisian financial services industry. Personnel Review, 43(4), 490-514.

Marimuthu, M., Arokiasamy, L., \& Ismail, M. (2009), Human capital development and its impact on firm performance: Evidence from developmental economics. Journal of international social research, 2(8).

Masterson, S. S., Lewis, K., Goldman, B. M., \& Taylor, M. S. (2000). Integrating justice and social exchange: The differing effects of fair procedures and treatment on work relationships. Academy of Management journal, 43(4), 738-748.

Mathieu, J. E., \&Zajac, D. M. (1990), A review and meta-analysis of the antecedents, correlates, and consequences of organizational commitment. Psychological bulletin, 108(2), 171.

Mathis,\& Jackson. (2000), Organization Commitment.Public Performance \& Managerial Review.

McWilliams, A., \& Siegel, D. (2001), Corporate social responsibility: A theory of the firm perspective. Academy ofmanagement review, 26(1), 117-127.

Méreaux, J. P., \&Feige, J. (2015), Changementorganizationnel «responsable» etoutils de gestionstratégique du capital humain. La Revue des Sciences de Gestion, (5), 41-48.

Meyer, J. P., \& Allen, N. J. (1991).A three-component conceptualization of organizational commitment. Human resource management review, 1(1), 61-89. 
Meyer, J. P., Paunonen, S. V., Gellatly, I. R., Goffin, R. D., \& Jackson, D. N. (1989), Organizational commitment and job performance: It's the nature of the commitment that counts. Journal of applied Psychology, 74(1), 152.

Mirvis, P. (2012), Employee engagement and CSR: Transactional, relational, and developmental approaches. California Management Review, 54(4), 93-117.

Morrison, R. L. (2008), Negative relationships in the workplace: Associations with organizational commitment, cohesion, job satisfaction and intention to turnover. Journal of Management \& Organization, 14(4), 330-344.

Mowday, R. T., Porter, L. W., \& Steers, R. (1982), Organizational linkage: the psychology of commitment, absenteeism and turnover. Organizational and Occupational Psychology, 10(3), 2008.

Mowday, R. T., Porter, L. W., \& Steers, R. M. (2013). Employee —organization linkages: The psychology of commitment, absenteeism, and turnover. Academic press.

(https://books.google.com/books?hl=en\&lr=\&id=f_FFBQAAQBAJ\&oi=fnd\&pg=PP1\&dq=Mowday,+R. + T., + Porter, + L. + W., $+\% 26+$ Steers, + R. + M.+(2013).+Employee $\%$ E2\%80\%94or ganization+linkages: + The + psychology + of + commitment, + absenteeism, + and + turnover + Academic + press.\&ots $=$ GkMtI5Le2\&sig=6uICFrfOb3hHNJvAtGmOQDoy7tM)

Nahapiet, J., \& Ghoshal, S. (1998). Social capital, intellectual capital, and the organizational advantage. Academy of management review, 23(2), 242-266.

Naylor, J. C., \& Pritchard, R. D. llgen, DR (1980), A theory of behaviour in organizations.

Nonaka, I., \& Takeuchi, H. (1995). The knowledge-creating company: How Japanese companies create the dynamics of innovation. Oxford university press.

Nordhaug, O. (1998), Competence specificities in organizations: a classificatory framework. International Studies of Management \& Organization, 28(1), 8-29.

Norris, D.R. and Niebuhr, R.E.(1984), Attributional influences on the job performance-job satisfaction relationship. Academy of Management Journal, 27(2), 424-431.

Ocen, E., Francis, K. and Angundaru, G.(2017), The role of training in building employee commitment: the mediating effect of job satisfaction. European Journal of Training and Development, 41(9), 742-757.

O'Reilly, C. A., \& Chatman, J. (1986), Organizational commitment and psychological attachment: The effects of compliance, identification, and internalization on prosocialbehavior. Journal of applied psychology, 71(3), 492.

Orlitzky, M. (2005), Social responsibility and financial performance: Trade-off or virtuous circle. University of Auckland Business Review, 7(1), 37-43.

Ostroff, C.(1992), The relationship between satisfaction, attitudes, and performance: An organizational level analysis. Journal of applied psychology, 76(6), 963.

Parker, S. K. (2003), Longitudinal effects of lean production on employee outcomes and the mediating role of work characteristics. Journal of applied psychology, 88(4), 620.

Porter, M. E., \& Kramer, M. R. (2006), The link between competitive advantage and corporate social responsibility. Harvard business review, 84(12), 78-92.

Porter, M. E., \& Kramer, M. R. (2011), The Big Idea: Creating Shared Value. How to reinvent capitalism—and unleash a wave of innovation and growth.Harvard Business Review, 89, (1-2).

Pritchard, R. D., Hollenback, J., \& DeLeo, P. J. (1980). The effects of continuous and partial schedules of reinforcement on effort, performance, and satisfaction. Organizational Behavior and Human Performance, 25(3), 336-353.

Psacharopoulos, G. (1985). Returns to education: a further international update and implications. Journal of Human resources, 22(4), 583-604. 
Rahiman, M. H. U., \&Kodikal, R. (2017), Impact of Employee Work Related Attitudes on Job Performance. British journal of Economics, Finance and Management Sciences, 13(2), 93-105.

Randall, D. M. (1990). The consequences of organizational commitment: Methodological investigation. Journal of organizational Behavior, 11(5), 361-378.

Rettab, B., Brik, A.B. and Mellahi, K. (2008), A study of management perceptions of the impact of corporate social responsibility on organizational performance in emerging economies: the case of Dubai. Journal of Business Ethics, 89, 371-90.

Riasat, F., Aslam, S. and Nisar, Q.A. (2016), Do Intrinsic and Extrinsic Rewards influence the Job satisfaction and Job performance?Mediating Role of Reward System.Journal of Management Info, 11(1), 16-34.

Riketta, M. (2002). Attitudinal organizational commitment and job performance: a meta-analysis. Journal of organizational behavior, 23(3), 257-266.

Robbins, S. P., \& Judge, T. A. (2006). Perilaku organisasi. Edisi kesepuluh. Jakarta: PT Indeks Kelompok Gramedia.(http://www.academia.edu/download/43791329/RESUME_PERILAKU_ORGANISASI.docx)

Roberts, P. W., \& Dowling, G. R. (2002), Corporate reputation and sustained superior financial performance. Strategic management journal, 23(12), 1077-1093.

Roethlisberger, F.J. (1959). Management and Morale. Cambridge, M.A: Harvard University Press.

Romer, P. M. (1990), capital, labor, and productivity.Brookings papers on economic activity. Microeconomics, 1990,337-367.

Roos, J., Roos, G., Dragonetti, N. C., \& Edvinsson, L. (1997). Consolidating intellectual capital measurements: The IC-Index approach. In Intellectual Capital (pp. 78-101). Palgrave Macmillan, London.

Rucci, A. J., Kirn, S. P., \& Quinn, R. T. (1998), The employee-customer-profit chain at Sears. Harvard Business Review, 76, 82-98.

RYAN, A., Schmit, M. J., \& Johnson, R. (1996), Attitudes and effectiveness: Examining relations at an organizational level. Personnel psychology, 49(4), 853-882.

Sadikoglu, E., \&Zehir, C. (2010).Investigating the effects of innovation and employee performance on the relationship between total quality management practices and firm performance: An empirical study of Turkish firms.International journal of production economics, 127(1), 13-26.

Sageer, A., Rafat, S. and Agarwal, P.(2012), Identification of variables affecting employee satisfaction and their impact on the organization. IOSR Journal of business and management, 5(1), 32-39.

Santhosh, M., \&Baral, R. (2015), The moderating role of top management support in the link between CSR and employee engagement-a conceptual framework. Journal of Contemporary Management Research, 9(2), 1.

Sasser, W. E., Schlesinger, L. A., \& Heskett, J. L. (1997). Service profit chain. Simon and Schuster. https://books.google.com/books?hl=en\&lr=\&id=f8PpwCgtp9MC\&oi=fnd\&pg=PT18\&dq=Sasser, +W.+E., + Schlesinger, + L. + A. + W., $+\% 26+$ Heskett, + J. + L. $+(1997),+$ Service + profit + chain\&ots $=$ PQ3hvOgzk9\&sig $=$ eWcZQSgoi4MtOIK5tpcXrqxXaLc)

Schneider B, Hanges PJ, Smith B, Salvaggio AN. Which comes first: employee attitudes or

Schultz, T. W. (1961), Investment in human capital. The American economic review, 51(1), 1-17.

Shen, J., \& Benson, J. (2016), When CSR is a social norm: How socially responsible human resource management affects employee work behavior. Journal of Management, 42(6), 1723-1746.

Shen, J., \&Jiuhua Zhu, C. (2011), Effects of socially responsible human resource management on employee organizational commitment. The International Journal of Human Resource Management, 22(15), 30203035.

Shore, L.M. and Martin, H.J.(1989), Job satisfaction and organizational commitment in relation to work performance and turnover intentions. Human relations, 42(7), 625-638. 
Spector, P. E. (2008). Industrial and Organizational Psychology. Research and. Practice.

Startseva, E., Gurvits, N., \&Sidorova, I. (2015), Human Capital Reporting and its Linkage with Key Performance Indicators of Companies: Evidence from Estonian Companies Listed on Nasdax OMX Baltic. Central European Business Review, 4(4), 48.

Steers, R. M. (1977), Antecedents and outcomes of organizational commitment.Administrative science quarterly, 22(1), 46-56.

Steers, R. M., \& Rhodes, S. R. (1978), Major influences on employee attendance: A process model.Journal of applied Psychology, 63(4), 391.

Storey, J. (1989), Introduction: from personnel management to human resource management. New perspectives on human resource management, $1,18$.

Story, J., \&Neves, P. (2015), When corporate social responsibility (CSR) increases performance: exploring the role of intrinsic and extrinsic CSR attribution. Business Ethics: A European Review, 24(2), 111-124.

Tang, T. L. P., Singer, M. G., \& Roberts, S. (2000). Employees' perceived organizational instrumentality: An examination of the gender differences. Journal of Managerial Psychology.

Testa, M. R., Skaruppa, C., \&Pietrzak, D. (1998), Linking job satisfaction and customer satisfaction in the cruise industry: implications for hospitality and travel organizations. Journal of Hospitality \& Tourism Research, 22(1), 4-14.

Torugsa, N. A., O'Donohue, W., \&Hecker, R. (2012), Capabilities, proactive CSR and financial performance in SMEs: Empirical evidence from an Australian manufacturing industry sector. Journal of business ethics, 109(4), 483-500.

Turker, D 2009, How Corporate Social Responsibility Influences Organizational Commitment. Journal of Business Ethics, 89, 189-204.

Ulrich, D. (1998), Intellectual capital= competence x commitment. Sloan management review, 39(2), 15.

Van Der Wiele, T., Boselie, P., \&Hesselink, M. (2002), Empirical evidence for the relationship between customer satisfaction and business performance.Managing Service Quality: An International Journal, 12(3), 184-193.

Verkhohlyad, O., \& McLean, G. N. (2012), Applying organizational commitment and human capital theories to emigration research.European Journal of Training and Development, 36(2/3), 308-328.

Wiener, Y., \&Vardi, Y. (1980). Relationships between job, organization, and career commitments and work outcomes-An integrative approach. Organizational Behavior and Human Performance, 26(1), 81-96.

Wilson, A. (1997), Business and its social responsibility. Current issues in business ethics, 50-59.

Wright, P. M., Snell, S. A., \& Dyer, L. (2005), New models of strategic HRM in a global context. The International Journal of Human Resource Management, 16(6), 875-881.

Yates, L.A.(2014), Exploring the relationship of ethical leadership with job satisfaction, organizational commitment, and organizational citizenship behaviour. The Journal of Values-Based Leadership, 7(1) 4.

Zadeh, M. (2014), Examining the relationship between the intellectual capital and the staff performance. Management Science Letters, 4(4), 813-818.

ZWETSLOOT G. I. J. M., MARREWIJK M. N. A. V., (2004), From Quality to Sustainability, in: Journal of Business Ethics, 55, 79-82. 
